\title{
A STUDY OF SEROPREVALENCE OF TRANSFUSION TRANSMITTED INFECTIONS (TTIS) IN BLOOD DONORS OF ANANTAPUR DISTRICT IN ANDHRA PRADESH
}

\author{
Vankadari Sowjanya Lakshmi', Sindhu Priya Devarashetty2, Niharika Borugadda ${ }^{3}$, Tirunamala Chenchu Subbarayula Suman Kumar ${ }^{4}$
}

${ }^{1}$ Tutor, Department of Pulmonary Medicine, GMC, Anantapuramu.

${ }^{2}$ House Officer at Aware Global Hospitals, Hyderabad.

${ }^{3}$ Assistant Professor, Department of Community Medicine, VBMC, Kurnool.

4 Tutor, Department of Pathology, GMC, Anantapuramu.

\section{ABSTRACT}

Transfusion Transmitted Infections (TTI) play an important role in disease causation. Screening for various TTIs is very important at blood banks, which helps in reducing the seroprevalence of TTIs in general population.

\section{AIMS AND OBJECTIVES}

1. To estimate the seroprevalence of TTIs in Anantapur district over a period of 6 months.

2. To study the association between Rh type of the blood group and the prevalence of TTIs.

\section{MATERIALS AND METHODS}

Record based study; Blood donor's data and details of common TTIs screened at blood bank along with Rh type of their blood groups was collected over a period of six months and subjected to data analysis using proportions and chi-square test.

\section{RESULTS}

The total sample size was 1688 . Overall seroprevalence of TTIs is $2.42 \%$. The seroprevalence of individual TTI i.e. HIV, Hep B, Hep C, Syphilis and malaria was $0.1 \%, 1.9 \%, 0.24 \%, 0.18 \%$ and $0 \%$ respectively. There was no significant association found between presence of TTI and Rh type of the blood donor.

\section{CONCLUSION}

The burden of TTI is quite high and steps to be taken to maintain the quality of screening methods in blood banks to reduce the risk of TTI in general population.

\section{KEYWORDS}

Transfusion Transmitted Infection, Seroprevalence, Rh Type.

HOW TO CITE THIS ARTICLE: Lakshmi VS, Devarashetty SP, Borugadda N, et al. A study of seroprevalence of transfusion transmitted infections (TTIS) in blood donors of Anantapur district in Andhra Pradesh. J. Evolution Med. Dent. Sci. 2016;5(74): 5456-5458, DOI: $10.14260 /$ jemds/2016/1235

\section{INTRODUCTION \\ Transfusion Transmitted Infection (TTI) is defined as any infection that is transmitted from infected donor to recipient through parenteral administration of blood and its products. ${ }^{1}$ Blood transfusion is a lifesaving procedure in emergencies. However, it is not without risk and cause infections to the recipient. Thus necessary precautions must be taken while collecting blood from the donor and giving the same to the recipient like taking thorough history and physical examination of donor, screening tests to detect pathogens that are transfused through blood, decontamination of received blood and maintaining hygiene conditions while transfusing blood. The major problem is the donor might be in window period and undergoing seroconversion while donating blood. ${ }^{2}$}

Financial or Other, Competing Interest: None.

Submission 02-08-2016, Peer Review 01-09-2016,

Acceptance 07-09-2016, Published 14-09-2016.

Corresponding Author:

Dr. Niharika Borugadda,

S2, Block 1, Medical College Teaching Staff Quarters,

Beside Power Office,

Jesus Nagar,

Anantapuram-515001,

Andhra Pradesh.

E-mail: dr.niharika2008@gmail.com

DOI: 10.14260/jemds/2016/1235

\section{(c) $(1)$}

Such people represent new infection in the community. According to WHO guidelines the common infections that are screened in India before blood transfusion are Human Immunodeficiency Virus (HIV), Hepatitis B Virus (HBV), Hepatitis C Virus (HCV), Human T Lymphocyte Virus (HTLV-1) and Syphilis. ${ }^{3}$

The prevalence had dramatically decreased in some countries, whereas it is in increasing trend in developing countries because of lack of resources for screening the blood. ${ }^{4}$ More initiatives have to be taken to cut down these infections. TTI's are significant burden to the society.

The overall prevalence of Transfusion Transmitted Infections (TTIs) ranges from $2.79 \%$ to $18.7 \%$ according to various studies. $5,6,7$

The prevalence of HIV according to various studies was ranging from $0.2-8.5 \%$; similarly, HBsAg was ranging from $1.2-10.6 \%$, whereas HCV ranges from $0-1.3 \%$, Syphilis from $0.1-0.66 \% .5,6,7,8,9,10,11,12$

Majority of the studies showed no malaria positive cases, whereas in Negi G et al study, conducted in Uttarakhand (India), the prevalence of malaria was $0.002 \% .13$

Students were less commonly involved than the employed individuals.6,10 Males were more commonly affected than females. 9,11 According to few studies, Rh Negative blood group, especially 'A' Negative and 'B' Negative 
blood groups, were commonly found 'reactive' for at least one type of Transfusion Transmitted Infection.3,7,10

The present study has been undertaken to estimate the burden of TTIs in a semi-urban district of Andhra Pradesh.

\section{AIMS AND OBJECTIVES}

1. To estimate the seroprevalence of TTIs in Anantapur district over a period of 6 months.

2. To study the association between Rh type of the blood group and the prevalence of TTIs.

\section{MATERIALS AND METHODS}

A record-based study has been conducted in a blood bank located in Anantapur district of Andhra Pradesh. Data was collected regarding the overall no. of donors in a period of six months (i.e. from Dec 2015 to May 2016) and total no. of donors with commonly screened TTIs like HIV, Hep-B, Hep-C, Syphilis and Malaria.

The method used for screening HIV, Hep B and Hep C is ELISA (Merilisa Gen 4). Syphilis was screened with RPR Card Test and Malaria was screened using Pan malaria card, i.e. Rapid Visual Antigen Test for the detection of infection with Plasmodium species.

Data thus obtained has been analysed using proportions and chi-square test with the help of MS-Excel and OpenEpi (online version) software.

\section{RESULTS}

In a period of six months, the total no. of donors were 1688 . Among them, only 3 out of $1688(0.2 \%)$ subjects were females and 1685 (99.8\%) subjects were males. Around 218 subjects were voluntary donors and the remaining 1470 were replacement donors.

The overall prevalence of Transfusion Transmitted Infections was $2.42 \%(41 / 1688)$ in the present study.

\begin{tabular}{|c|c|c|}
\hline $\begin{array}{c}\text { Transfusion } \\
\text { Transmitted } \\
\text { Infection }\end{array}$ & $\begin{array}{c}\text { No. of Donors } \\
\text { 'Reactive' Out of } \\
\text { Total Sample of } \\
\mathbf{1 6 8 8}\end{array}$ & $\begin{array}{c}\text { Seroprevalence } \\
\text { (\%) }\end{array}$ \\
\hline HIV & 2 & $0.1 \%$ \\
\hline HbsAg & 32 & $1.9 \%$ \\
\hline HCV & 4 & $0.24 \%$ \\
\hline Syphilis & 3 & $0.18 \%$ \\
\hline Malaria & 0 & $0 \%$ \\
\hline \multicolumn{2}{|c|}{ Total } & $\mathbf{4 1}$ \\
\hline \multicolumn{2}{|c|}{ Table 1: Table showing the Seroprevalence of } \\
\multicolumn{2}{|c|}{ Various TTIs in Blood Donors } \\
\hline
\end{tabular}

Among the total 1688 subjects, only two cases of HIV was screened over a period of six months. Around 32 out of 1688 donors (1.89\%) were HBsAg 'Reactive.' Similarly, HCV 'Reactive' were around $4(0.24 \%)$ and Syphilis were around 3 subjects $(0.18 \%)$. Not a single case of malaria was screened over a period of six months (Table 1, Fig. 1).

\section{Fig 1: Bar Chart showing the seroprevalence of various TTIs}

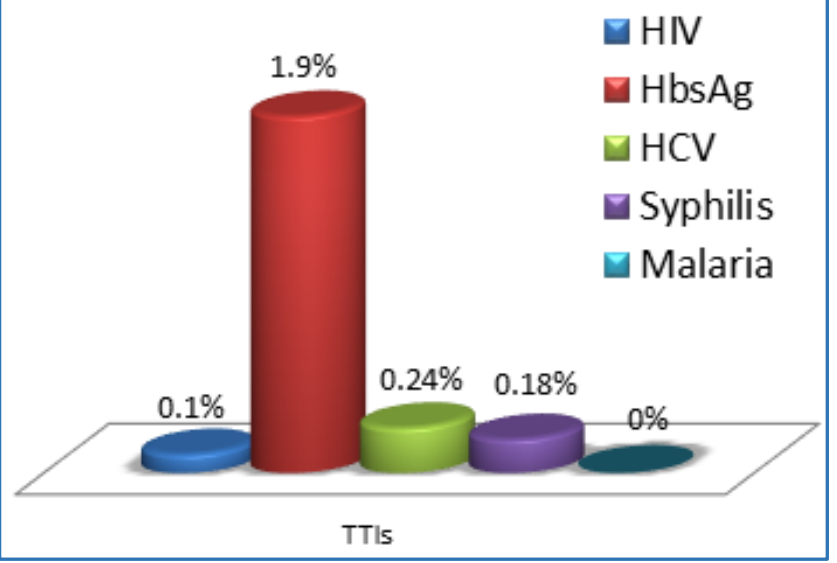

\begin{tabular}{|c|c|c|c|}
\hline $\begin{array}{c}\text { TTI Vs Rh } \\
\text { Type }\end{array}$ & $\begin{array}{c}\text { TTI } \\
\text { Present }\end{array}$ & TTI Absent & Total \\
\hline Rh Positive & $37(2.3 \%)$ & $\begin{array}{c}1570 \\
(97.7 \%)\end{array}$ & $\begin{array}{c}1607 \\
(100 \%)\end{array}$ \\
\hline $\begin{array}{c}\text { Rh } \\
\text { Negative }\end{array}$ & $4(4.9 \%)$ & $77(95.1 \%)$ & $81(100 \%)$ \\
\hline Total & $\mathbf{4 1}(\mathbf{2 . 4 \% )}$ & $\begin{array}{c}\mathbf{1 6 4 9} \\
(\mathbf{9 7 . 6} \%)\end{array}$ & $\begin{array}{c}\mathbf{1 6 8 8} \\
(\mathbf{1 0 0} \%)\end{array}$ \\
\hline \multicolumn{4}{|c|}{ Table 2: Table Illustrating Association between } \\
TTIs and Rh Type of the Donors
\end{tabular}

Chi-square $=1.285, p>0.05$, Not Significant

Among the total sample of 1688,41 donors had at least one type of TTI; among them 37 donors $(2.3 \%)$ were of Rh 'positive' blood group and 4 donors (4.9\%) were belonging to $\mathrm{Rh}$ 'negative' blood group. The above finding was falling short of significance, thus it needs further research (Table 2).

\section{DISCUSSION}

The total sample size of the present study is 1688 . In the present study, overall seroprevalence of TTI was $2.42 \%$ ( 41 out of 1688), which is comparable to the prevalence of TTI in Karmakar PR et al study $(2.79 \%)$ conducted at Kolkata in the year 2014.5

The seroprevalence of HIV in the present study was $0.1 \%$, comparable with that of Sharma et al $(0.3 \%)$ and Negi G et al studies. ${ }^{11,13}$

The seroprevalence of HbsAg in the present study was $1.9 \%$, which is comparable to Karmakar et al study conducted at Kolkata (1.41\%) and also Yildiz et al study (1.66\%).5,8

Similarly, the proportion of HCV 'Reactive' donors in the present study was $0.24 \%$, very much comparable to the study done by Pallavi $\mathrm{P}$ et al at Mysore. ${ }^{9}$

The seroprevalence of the syphilis in the present study was $0.18 \%$, which was comparable to the findings in Karmakar et al study $(0.23 \%)$ and Pallavi $\mathrm{P}$ et al study $(0.28 \%) .5,9$ 
There were no donors who were positive for malarial parasite in the present study; a similar finding was given by Pallavi et al and Negi G et al.9,13

$\mathrm{Rh}$ negative blood groups (2.3\%) were found to be slightly higher in proportion when compared to $\mathrm{Rh}$ positive blood groups (4.9\%) among the donors 'reactive' for TTIs; a similar finding was given by Makroo RN et al, Stokx J et al and Tyagi $S$ et al studies. $3,7,10$

There is significant transmission of infection from male donors of all age groups in the present study comparable to majority of the studies, but this finding needs further research as there was no proper representation of female population in the sample size. ${ }^{3,9,11,12}$ HIV and HbsAg transmission was more common than other TTI's.

\section{RECOMMENDATIONS}

There is a need to implement highly sensitive and specific procedures to decrease the transmission, as there was high prevalence of TTIs among blood donors; for example, proper donor selection, discouraging professional blood donors, screening for both HIV-1 and HIV-2 would be helpful. There are many factors that have to be taken into account for the reduction of TTI's like maintaining qualified and trained staff, having adequate resources for consistent and reliable screening, having national system for evaluation and validation of assays used for blood screening.

There is an urgent need to develop a national program for TTI's to ensure a secured and sufficient blood supply. Steps are also to be taken for screening minor TTI's too. The ultimate goal of the program has to be to provide a Transfusion Transmitted Infection free blood supply to the beneficiaries and maintain a healthy society.

\section{REFERENCES}

1. Communicable disease control, transfusion transmissible infection. BC center for disease control 2004:1. http://www.bccdc.ca.

2. Viswanathan C. Are our donors safe? Indian J Pediatr 2001;68(1):69-75.

3. Makroo RN, Hegde V, Chowdhry M, et al. Seroprevalence of infectious markers \& their trends in blood donors in a hospital based blood bank in north India. Indian J Med Res 2015;142(3):317-22.
4. Fernandes H, D'souza PF, D'souza PM. Prevalence of transfusion transmitted infections in voluntary and replacement donors. Indian J Hematol Blood Transfus 2010;26(3):89-91.

5. Karmakar PR, Shrivastava P, Ray TG. Seroprevalence of transfusion transmissible infections among blood donors at the blood bank of a medical college of Kolkata. Indian J Public Health 2014;58(1):61-4.

6. Birhaneselassie M. Prevalence of transfusiontransmissible infections in donors to an ethiopian blood bank between 2009 and 2013 and donation factors that would improve the safety of the blood supply in underdeveloped countries. Lab Med 2016;47(2):134-9.

7. Stokx J, Gillet P, De Weggheleire, et al. Seroprevalence of transfusion-transmissible infections and evaluation of the pre-donation screening performance at the provincial hospital of Tete, Mozambique. BMC Infect Dis 2011;11:141.

8. Yildiz SM, Candevir A, Kibar F, et al. Hepatitis B, Hepatitis C, HIV and syphilis frequency among blood donors: a single center study. Transfus Apher Sci 2015;53(3):30814.

9. Pallavi P, Ganesh CK, Jayashree K, et al. Seroprevalence and trends in transfusion transmitted infections among blood donors in a university hospital blood bank: a 5 year study. Indian J Hematol Blood Transfus 2011;27(1):1-6.

10. Tyagi S, Tyagi A. Possible correlation of transfusion transmitted diseases with Rh type and ABO blood group system. J Clin Diagn Res 2013;7(9):1930-1.

11. Sharma RR, Cheema R, Vajpayee M, et al. Prevalence of markers of transfusion transmissible diseases in voluntary and replacement blood donors. Natl Med J India 2004;17(1):19-21.

12. Giri PA, Deshpande JD, Phalke DB, et al. Seroprevalence of transfusion transmissible infections among voluntary blood donors at a tertiary care teaching hospital in rural area of India. J Family Med Prim Care 2012;1(1):48-51.

13. Negi G, Gaur DS. Trends of transfusion transmissible diseases among blood donors at Uttarakhand, India. Indian J Community Med 2014;39(3):183-6. 